\title{
Zuzanna Krótki
}

\section{Z historii leksemów: gzić się, grzać się, parzyć się, bzykać się}

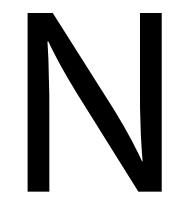

adanie znaczenia przenośnego nazwom zwierząt prowadzi do utraty prymarnie neutralnego statusu jednostek leksykalnych. W większości przypadków łączy się z deprecjacja istoty ludzkiej (Grybosiowa, 2003, s. 12; Krótki, 2012, s. 97), dowodem czego są np. takie ekspresywizmy, jak: świnia, osioł, żreć, ale również czasowniki gzić się, parzyć się, grzać się, bzykać się. Przywołane leksemy wskazują na zwierzęce, czyli nieprzystające człowiekowi, sposoby zachowań, dlatego ich ekspresja jest negatywna.

Przedmiotem mojego opracowania jest analiza czterech czasowników, które prymarnie nazywały zwierzęce zachowania, świadczące o popędzie płciowym, natomiast sekundarnie stały się wulgarnymi określeniami czynności seksualnych. Wychodząc od etymologii, zbadam, w jakim momencie wyrazy te zostały obłożone tabu językowym.

\section{Pojęcie tabu językowego oraz wulgaryzmu}

Wyraz tabu obejmuje swym znaczeniem dwie sfery o charakterze ambiwalentnym. Z jednej strony oznacza 'coś świętego', z drugiej 'coś, co stanowi zaprzeczenie tej świętości'. Według Wilhelma Wundta tabu to nic innego jak najstarszy, niepisany zakaz ludzkości, którego celami bezpośrednimi są: ochrona ważnych osób (kapłanów, władców), zabezpieczenie słabych (kobiet, dzieci), uniemożliwienie kontaktu ze zwłokami, a także ochrona przed zaburzeniem ważnych momentów życiowych, takich jak np.: męska inicjacja, poród, zabez- 
pieczenie przed ryzykiem wychowywania nie swoich dzieci czy ochrona nienarodzonego płodu (Freud, 1997, ss. 34-35).

Zygmunt Freud (1997, s. 43) zauważył natomiast, że rdzeń tabu stanowi akt dotknięcia. Zakaz dotykania obejmuje nie tylko bezpośredni kontakt z tym, co jest tabu, ale także przenośne użycie zwrotu stykać się z kim/z czym. Wszystko, co kieruje myśli i pragnienia w stronę tabu, powoduje nawiązanie z nim kontaktu mentalnego, który jest tak samo zabroniony, jak bezpośrednie zetknięcie fizyczne (Krótki, 2014, ss. 140-143). Ten właśnie nakaz niedopuszczania do siebie myśli o tabu ogólnym (tabou général) stał się przyczyną wyodrębnienia tabu językowego (tabou linguistique) (Widłak, 1968, s. 7).

Przyjęło się, że tabu językowe może dotyczyć zarówno planu treści, jak i planu wyrażenia (Leszczyński, 1988, s. 28). W pierwszym wypadku chodzi o „tabu zapobiegawcze”, czyli ogół tematów, które w pewnych grupach społecznych nie powinny być podejmowane (Widłak, 1968, s. 15), w drugim - o jednostki leksykalne o zbyt emocjonalnym nacechowaniu.

Leksemy, które będą analizowane w tym szkicu, są wyrazami objętymi tabu w planie wyrażenia, zaliczanymi do zbioru polskich wulgaryzmów. Leksem wulgaryzm rozumiem w sposób bardzo szeroki - jako 'jednostkę leksykalną, za pomocą której mówiący ujawnia swoje emocje względem kogoś lub czegoś, łamiąc przy tym tabu językowe' (Grochowski, 1995, s. 15).

Maciej Grochowski wyróżnił dwa rodzaje wulgaryzmów: wulgaryzmy systemowe oraz wulgaryzmy referencyjno-obyczajowe (Grochowski, 1995, s. 16). Pierwszy z wymienionych terminów mieści jednostki leksykalne objęte tabu wyłącznie ze względu na ich cechy wyrażeniowe (formalne), inaczej mówiąc niezależne od ich właściwości semantycznych i kontekstu użycia. Za pomocą wulgaryzmów systemowych naruszane są przede wszystkim konwencje językowe, wtórnie kulturowe.

Z kolei wulgaryzmy referencyjno-obyczajowe to jednostki leksykalne uznane za tabu ze względu na ich cechę semantyczną i zakres odniesienia przedmiotowego. Relacje pomiędzy tymi wyrażeniami a zbiorem jednostek języka ogólnego są zmienne, toteż nieraz nie sposób odpowiedzieć na pytanie, czy dany wulgaryzm obyczajowy jest rozpowszechniony w języku ogólnym, czy jedynie w określonych środowiskach społecznych. Może także należeć wyłącznie do czyjegoś idiolektu.

Fakt ten zdecydowanie utrudnia analizy o charakterze diachronicznym. Ze współczesnego punktu widzenia jednostki gzić się, grzać się, parzyć się, bzykać się to wulgaryzmy systemowe. Zastanawia jednak to, czy w ich historii był taki etap, w którym sytuowały się 
one w kategorii wulgaryzmów refleksyjno-obyczajowych. Zdaję sobie sprawę z tego, że w wielu wypadkach wskazanie momentu zmiany funkcji poszczególnych wulgaryzmów nie jest ani możliwe, ani zasadne. W artykule szczególną uwagę skieruję zatem na zmiany w treściach tych jednostek, jeśli natomiast bezsprzecznie można będzie orzec o charakterze danego wulgaryzmu, takie informacje pojawią się w niniejszym tekście.

\section{Zmiany w znaczeniach leksemów motywowanych zachowaniami „zwierzęcymi”}

\section{Leksem gzić się}

Czasownik gzić się to, poświadczony już w staropolszczyźnie, derywat odimienny. Za jego podstawę uznaje się rzeczownik giez 'owad z rodziny Oestridae (Hypoderma bovis), pasożytujący pod skórą bydła' (SSław, SBor). Etymologia tego wyrazu nie jest pewna. Niektórzy badacze (SBr, SBor, SBań) upatrują źródeł tej jednostki w cząstce naśladującej odgłosy gza, inni zestawiają giez (płn.-słow. * $g$ gzb) z psł. rzeczownikami, oznaczającymi 'guz, narośl', tj.: *gydъ, * gyzdъ, gyža, guzъ (SSław). Według Franciszka Sławskiego (SSław) żadna z wymienionych hipotez nie jest wystarczająco przekonująca.

Nie ulega jednak wątpliwości, że pod wpływem polskiego giez powstały takie jednostki, jak ukraińskie hedz, gedz, gedzb 'giez' (SSław), dolnołużyckie gzik 'ślepak, owad' (SSław, SBor), białoruskie hiz 'mucha, owad' (SBor) oraz litewskie gužĕti 'śpieszyć się, biec tłumnie' (SSław). Wszystkie wymienione wyrazy posiadają znaczenia dziedziczone z polskiego giez. Nawet litewski czasownik gužěti nawiązuje do polskich źródeł, bowiem w niektórych staropolskich użyciach gies nazywał 'nerwowe zachowanie zwierząt, spowodowane ukąszeniem owadów' (SSław).

Co ciekawe, przywołany sens obecny był w treści rzeczownika gies tylko w XIV i w XV wieku. W kolejnym stuleciu w zbliżonej funkcji występował, powstały od giez, czasownik gzić się (jednostka ta, jak wiadomo, miała charakter werbalny, a nie nominalny). Jednak wyraz ten poza sensem 'wykonywać dziwne ruchy po ukąszeniu przez gzy' posiadał dwa inne znaczenia: (1.) 'biegać, skakać, dokazywać' (np. „I powinnaś to już rzec kołnierz Kuni, Rysi, iż ma zawżdy mędrszy być niż wilczy, a Lisi. Ano wierz mi nie głupi to obadwa byli, i kunki się przed nimi barzo czasem gzili". Rej Zwierz 101 v, SXVI) oraz (2.) 'odczuwać popęd płciowy przez zwierzęta' („,Catullio, Dieitur de canibus, quando venerem appetunt, gzić się. 
Ut, Catuliunt canes, gżą się psy. Mącz 41c., SXVI). Geneza pierwszej spośród wymienionych treści wydaje się dość oczywista - wyłoniła się ona na skutek skojarzenia nadpobudliwości z zachowaniem zwierząt ukąszonych przez gzy.

O wiele bardziej problematyczne wydaje się wskazanie motywacji drugiego znaczenia. Aby dociec jego genezy, należy sięgnąć do podręczników przyrodniczych. W jednym z nich odnaleźć można informację, że giez bydlęcy jest największym postrachem bydła spośród wszystkich owadów i pasożytów. Na odgłos jego brzęczenia zwierzęta energicznie oganiają się ogonem, po czym galopem uciekają do miejsc zacienionych lub stawów (Banaszak, 1994, s. 58). Opisywane piętrzenie się bydlęcych ciał oraz ruch ogona zestawione zostały z zachowaniem świadczącym o zwierzęcym popędzie płciowym, w rezultacie czego czasownik gzić się zaczął oznaczać 'odczuwać popęd płciowy'.

Oba przywołane wyżej sensy (zarówno 'biegać, skakać, dokazywać', jak i 'odczuwać popęd seksualny przez zwierzęta') kontynuowane były w XVII i XVIII wieku, np.:

gzić 'kąsać': Bący i gzicy gżą bydło. $\operatorname{Tr}(\mathrm{SL})$;

gzić 'odczuwać popęd płciowy’: Czas gżenia się bydła, bekowisko, gżenie się, gies.

pr. et. fig. tr. (SL).

Na szczególną uwagę zasługuje zwłaszcza drugi cytat, w którym pojawia się, niepoświadczony ani w XVI, ani w XVII wieku rzeczownik gies. Zapewne leksem ten obecny był w słowniku użytkowników polszczyzny początku i połowy doby średniopolskiej, z tym że aktualnie nie sposób dociec jego znaczenia. Niewykluczone, że już w tym czasie gies posiadał taką samą treść semantyczną jak w XVIII wieku, tj. 'odczuwać popęd przez zwierzęta', niemniej brakuje jakichkolwiek dowodów potwierdzających tę hipotezę.

Zarejestrowano natomiast wiele przykładów świadczących o tym, że od XVII wieku rzeczownik gzik odnosił się do zwierzęcego popędu. Jego historia była jednak dość zawiła. Jeszcze w XVI stuleciu wyraz ten stanowił bowiem wyłącznie deminutivum od giez, charakteryzujące małego gza, np.:

asilus, buecenties, oestrum Calep, Cn; tabanus Calep; solipaga, solipuga Cn (4): Asilus bąk, gzik konie szczypiący. Calep 102a; Tabanus - Gzik, bąk siekęci bydło". Calep 1043a, 141 b, [725]b (SXVI);

Trzeba je [bydło] też lecie w chłodnej oborze zamykać by ich chrobacy nie jadły, abo gzikowie ktorzy je pod ogonem szczypiąc do lasa wyganiają. p. Crescentius, O pomnożeniu i rozkrzewieniu wszelakich pożytkow ksiąg dwojenaście..., Kraków 1571, 548 , Linde, (SXVI). 
Przywołana wyżej treść utrzymywała się jeszcze w XVII wieku, niemniej na równi z nią funkcjonował w tym czasie sens 'gżenie się, czas gżenia się bydła' (SJPXVII), np. „Abo bydło na wszystkie cztery świata strony lecą na gzik dźwignąwszy do góry ogony". Pot Pocz 141 (SJPXVII). Warto dodać, że cytowany fragment Pocztu herbów szlachty autorstwa Wacława Potockiego nie stanowi o indywidualizacji tegoż pisarza, wprost przeciwnie, w polszczyźnie XVIII wieku znajdujemy wiele fragmentów, w których gzik znaczy 'popęd zwierząt'. Istotniejsza wydaje się jednak inna kwestia, mianowicie to, od kiedy (i czy w ogóle) jednostki gzić się, gies oraz gzik były wulgaryzmami, odnoszącymi się do stosunku seksualnego.

W osiemnastowiecznej polszczyźnie odnotowano poświadczenia, na podstawie których można wnioskować, że czasownik gzić się nie posiadał pejoratywnego nacechowania, można nawet odnieść wrażenie, że jego wartość była dodatnia. Wyraz ten oznaczał po prostu 'pałać miłością,', np. „Wierne kochania różną postać mienią. Gżą się, weselą, drżą, bledną, rumienią". Zab. 9, 170 (SL).

Neutralne, a niejednokrotnie nawet pozytywne, konotacje miał również rzeczownik gzik, rozumiany jako '„szaleństwo z zbytniego kochania lub radości” (SL)'. W takim znaczeniu wyraz ten traktować należy jako synonim swawoli (figli) lub impulsu, bodźca, także popędu (nawet seksualnego), popychającego ludzi do jakichś działań (niekoniecznie słusznych). Zdarzały się jednak także użycia, w których gzik oznaczał również 'upał':

gzik 'upał': Już czwarty raz nasze gzik żniwa dogrzewał, jakom nie chciała słuchać jego pienia. Zab. 12, 35 (SL);

gzik 'swawola, uciecha, figle': Lud go ujrzawszy, ledwo żyw z pociechy, rośnie, stroi huczki, gziki, śmiechy. Zab. 12, 77 (SL);

gzik 'impuls': Wezyr za prawo mając gzik swej woli, może Baszom życie wydrzeć, kiedy zechce. Zab. 15, 71 (SL);

gzik'popęd seksualny': Wolność, którą u Wenery miał, gziki w nim drażni. Zab. 14, 30 (SL).

Na podstawie zarejestrowanych w dobie średniopolskiej użyć nie można wnioskować o tym, jakoby któryś spośród analizowanych w tym podrozdziale leksemów (poza cytowanym wyżej fragmentem nie ma żadnego wyimka z jednostką gies) był wulgaryzmem. Sytuacja nie ulega praktycznie żadnej zmianie w kolejnym stuleciu, wszystkie informacje zawarte w SWil są bowiem paralelne względem danych ujętych w SL.

Mamy jednak podstawy do tego, by przypuszczać, że na początku XX wieku czasownik gzić się zaczynał pełnić funkcję wulgaryzmu o charakterze refleksyjno-obyczajowym. W artykule hasłowym, ujętym w SW, pojawiła się co prawda wzmianka, że leksem gzić się 
stanowił synonim figlować, żartować, zbytkować, dokazywać, swawolić, niemniej jako przykłady użycia podane zostały wyimki wskazujące na nieco inną treść semantyczną, tj.:

Samaś się po nocy gziła, mnie będzies głodu morzyła, gżą się po ugorach chłopcy, gzi się jak cielę z ogonem. Prz. (SW);

Podchmieleni mołojcy gzili się z podchmielonymi młodycami. Sien (SW).

Wszystkie przywołane użycia odnoszą się do nieprzyzwoitych igraszek o charakterze lubieżnym. Niewykluczone więc, że już na początku ubiegłego stulecia czasownik gzić się był jednostką o charakterze wulgarnym, chociaż taka adnotacja nie pojawiła się w leksykonie tego okresu.

Dopiero w SD badany czasownik objaśniony został jako 'o ludziach: swawolić, zbytkować, być w zabawie napastliwym (jak giez), zalecać się, oddawać się miłości zmysłowej' (SD). W takim też znaczeniu leksem gzić się zakwalifikowany został do zbioru wulgaryzmów. Ujęte w SD użycia nie pozostawiają również wątpliwości, że od połowy XX wieku gzić się to wulgaryzm systemowy, np.:

Pójdziesz do kopców, tylko się tam nie gzij. Reym. Ferm. I 86 (SD);

Ja nie po to tutaj przyszedłem, by z gamratkami gzić się i popić, ale na ciężki trud.

Gałcz. Wit. 19 (SD).

Ciekawe wydaje się także to, że jeszcze w SD rzeczownik gzik odnotowany został w takich samych znaczeniach jak w SL. Jestem jednak przekonana, że większość sensów, zawartych we wspomnianych leksykonach, już w połowie XX wieku została zapomniana. Obecnie gzik znaczy bowiem wyłącznie: 'owad pasożytujący w stadium larwy w przewodzie pokarmowym koni, kóz i innych zwierząt, powodujący schorzenia, czasem śmiertelne' (USJP).

\section{Leksem grzać się}

Czasownik grzać od początku swej historii implikował wysoką temperaturę. U jego źródeł leży bowiem pie. rdzeń * $g^{\underline{y} h e r-~ ' c i e p ł y, ~ g o r a ̨ c y ', ~ o b e c n y ~ t a k z ̇ e ~ w ~ c z e s k i m ~ h r ̌ a ́ t i, ~ r o s y j s k i m ~ g r e t b, ~}$ ukraińskim hriti, także w serbsko-chorwackim grïjati (SSław, SBor). Wszystkie przywołane słowoformy znaczyły prymarnie 'wydawać, przekazywać ciepło', jednak bardzo szybko nabywały nowych znaczeń.

Już w staropolszczyźnie czasownik grzać (w stronie czynnej) poza 'ocieplać' oznaczał 'zachęcać, zagrzewać do walki'. Funkcjonując w stronie zwrotnej, odnosił się natomiast do 
okresu godowego niektórych zwierząt domowych i dzikich (zwłaszcza psa, niedźwiedzia lub borsuka). Ponieważ pierwsza spośród wymienionych treści nie jest celem prowadzonych analiz, nie poświęcę jej więcej uwagi. Istotniejsza wydaje się natomiast motywacja drugiego znaczenia. Rozwinęło się ono na skutek skojarzenia "grzania się", czyli instynktownego przytulania się do siebie zmarzniętych zwierząt, z ich aktem płciowym.

Niemniej, chociaż już w dobie staropolskiej czasownik grzać (się) był leksemem „zwierzęcym", jeszcze w XVI wieku poświadczone zostały użycia, w których wyraz ten (w stronie czynnej) oznacza 'przytulać kogoś', np.:

Ktorzy cudzołożnikow i czuryłow jurnych bękarty podrzucone grzeją, karmią, pieszczą. Klon. Wor. 61 (SXVI);

Całując i obłapiając k sobie go przytuliła, piersi panieńskie jemu podawała, grzała, toliła jako nalepiej umiała. Opec. Żyw. 15 v (SXVI).

Cytowane wyżej fragmenty bardzo silnie implikują 'miłość matczyną'. Zdarzały się jednak w polszczyźnie omawianego okresu wyimki z leksemem grzać, odnoszące się do miłości zmysłowej, a nawet grzesznej, np.: „Ten Propertius miłosny i polski Tibulus [...] Czasem też na chciwych łoniech grzeje Kupidyna, pobudza łucznego matki pianorodnej syna". Klon Żal B4 (SXVI). Zawarty w przywołanym fragmencie zwrot grzać Kupidyna oznaczał 'pisać erotyki', czyli wiersze, w przekonaniu ówczesnych użytkowników języka, nieprzyzwoite.

W kolejnym stuleciu nie odnotowano jednak podobnych poświadczeń. Czasownik grzać posiadał w tym czasie tylko trzy znaczenia: 'stawać się coraz cieplejszym, powodować podniesienie swojej temperatury za pomocą źródła ciepła lub przez naturalne działanie', 'dodawać sobie sił, zapału, pobudzać się, zachęcać się' oraz oczywiście 'o zwierzętach: być w stanie podniecenia płciowego' (np. „Grzeję co [...] grzać się [...] 3) läufig werden, laufen als eine Hündin [...] 3) étre, entrer en chaleur; étre chaude; chaudier. § [...] 3) grzeje się sobaka. [...]". T. III 432-433., SJPXVII).

Nie stosowano jednak analizowanej jednostki jako nazwy czynności seksualnych czy odczuwania miłości przez ludzi. Taką funkcję pełniło inne verbum - gorzeć, jednak również w jego przypadku nie można mówić o wulgaryzmie:

Do wziętej Gryzeldy smutny Achil gore. Hul, Ow. 15 (SL);

Ktorem gorzał ku pięknej Dafnie, która się jeszcze ku niemu nie zajęła wzajemnym zapałem. Zab. 11, 81 (SL). 
Jeszcze w drugiej połowie doby nowopolskiej leksem grzać się wiązano wyłącznie ze zwierzęcym popędem (np. „Suka grzeje się", SW). Dopiero w SD pojawiła się wzmianka, że grzać się może również pełnić funkcję synonimu gzić się. Aktualne leksykony takiego znaczenia nie podają, chociaż, jak się wydaje, jest ono nadal obecne w języku niektórych użytkowników polszczyzny.

\section{Leksem parzyć się}

Leksem parzyć odziedziczony został z prasłowiańszczyzny, gdzie kauzatywny czasownik *pariti, *par'Q, powstały od *porěti, *porějo 'ulegać działaniu wilgoci, ciepła, psuć się' (SBor), znaczył 'powodować, że coś ulega działaniu wilgoci i ciepła, ogrzewać, okładać czymś gorącym, oblewać wrzątkiem' (SBor).

Przywołana treść semantyczna przeniesiona została na grunt polski, z tym że bardzo szybko, bowiem już w XVI wieku wyraz parzyć nabył nowych znaczeń, tj. 'przegrzewać, trzymać w cieple', 'powodować przez dotknięcie podrażnienia skóry (także po dotknięciu przez pokrzywę)', 'strzelać do kogoś' (SXVI). Od początku doby średniopolskiej badany leksem występuje również w stronie zwrotnej, znacząc: 'przegrzewać się wskutek noszenia zbyt ciepłej odzieży', 'doznawać oparzenia' oraz 'poddawać się rozgrzewającemu działaniu wody lub pary' (SXVI), np.:

Takowa pani ma się często parzyć, nad surowym prządzionem, a ma nad nim siedzieć, co nagoręcej zetrwać może, abowiem taka para płodowi barzo służy. Sien Lek 113 (SXVI);

Długo się w wannie parzysz, Pryszko pochodzona. Koc. Fr. 114 (SXVI).

Niezwykle istotny jest drugi cytat, a dokładniej zawarte w nim połączenie $w$ wannie się parzyć. Prymarnie oznaczało ono 'gorącą kąpiel', niemniej jego sekundarna treść (po dodaniu przydawki przyrodzonej) dotyczyła już 'współżycia płciowego', np.: „Stary miał priapismum, nieukładną mękę. Lecz była młodej żenie ta niemoc na rękę, bo się pan często parzył w przyrodzonej wannie." Koch. Fr. 59 (SXVI). Podobnie jak w przypadku innych, badanych wcześniej wyrazów nie mamy jednak pewności, czy na tym etapie rozwoju polszczyzny jednostka parzyć się w przyrodzonej wannie była wulgaryzmem (w każdym razie na pewno nie pełniła funkcji leksemu "zwierzęcego").

W XVIII wieku odnotowano natomiast cały szereg użyć, w których parzyć się odnosiło się do zwierzęcej kopulacji, np.: „Wiosna najwłaściwszym jest czasem, kiedy się ptaki parzą”. Kluk Zw. 2, 74 (SL); „Parzą się w gołębnikach niewinne gołębie”. Kochow. 208 (SL). Uważam 
jednak utożsamianie parzyć się w znaczeniu 'spółkować' z parzyć 'działać na coś wysoką temperaturą' za co najmniej wątpliwe.

W XVII wieku zarejestrowany został bowiem leksem homonimiczny względem parzyć, który rozumiano jako ',pary dobierać, do pary dobierać, w pary połączyć” (SL)'. Wyraz ten miał znaczenie dość szerokie, dotyczył wszak zarówno etapów tworzenia się związku mężczyzny i kobiety, jak i instynktownego dobierania się w pary przez zwierzęta, także krzyżowania niektórych gatunków zwierząt, np.:

Czas może rozróżnione serca znowu sparzyć. Pot. Arg. 747 (SL);

Przez umiejętność parzenia zwierząt cudzoziemskich z krajowymi, przyjść można do gatunków osobliwych. Kluk. Zw. 2, 389 (SL).

Omawiany stan rzeczy utrzymywał się jeszcze u początków XX wieku (SW, por. np. „Tak się w nim wielość męstwa i swoboda parzy' pot. 'jednoczy'), natomiast w połowie tego stulecia (SD) znaczenia leksemu parzyć (się) odnoszące się do ludzi zostają wyrugowane. Interesujące wydaje się jednak to, że na początku XXI wieku badany czasownik znów zaczęto stosować względem ludzi, z tym że od tego momentu stał się on wulgaryzmem systemowym (USJP, SSyn).

W gwarach miejskich oraz młodzieżowych coraz większą popularnością cieszy się z kolei zwrot parzyć herbatę, stanowiący kalkę angielskiego teabagging. Oznacza on 'skrajną formę seksu oralnego, polegającą na braniu do ust worka z jądrami mężczyzny, przy jednoczesnej stymulacji penisa drugą ręką' (SSlang). Związek ten niewiele jednak ma wspólnego $z$ analizowanym polem semantycznym.

\section{Leksem bzykać się}

Historia leksemu bzykać (bzyczeć) w porównaniu z dziejami innych, badanych wcześniej wyrazów nie jest długa. Jednostkę tę poświadczono bowiem dopiero w XVIII wieku w postaci bzikać 'pisnąć, zabrzęczeć' (np. „Rzekłby to mucha bziknęła, niby trąbiąc ku potrzebie". Zab. 13, 282, SL). Za jej podstawę uznaje się dźwiękonaśladowcze bzz, imitujące odgłos brzęczących owadów - głównie komarów i gzów (SSław, SBor, SBań). Nie powinno dziwić zatem to, że dawny, czeski czasownik bzikati znaczył 'nerwowo zachowywać się po ukąszeniu przez gzy (o zwierzętach)', natomiast rosyjski bzyk 'ryk spłoszonego bydła po ukąszeniu przez gzy' (SSław). W polszczyźnie takich sensów nie zarejestrowano, niemniej niepodważalne jest pokrewieństwo etymologiczne formacji gzić się i bzikać. 
W XIX wieku badany leksem zyskał obecną postać fonetyczną - bzykać, jego znaczenie jednak do końca XX wieku nie zmieniło się (por. 'o lecących owadach, pociskach i mechanizmach, mogących lecieć w powietrzu: wydawać dźwięk podobny do słabego gwizdu', SD).

Wulgaryzm bzykać się, znaczący 'współżyć', traktować zatem należy jako wyraz stosunkowo nowy, niemniej zarejestrowany już w USJP. W odróżnieniu od parzyć się czasownik ten figuruje nawet w SSlang, co, jak się wydaje, jeszcze mocniej podkreśla jego wulgarny charakter. Jako przykład przytoczę kilka fragmentów z tegoż leksykonu:

bzykać się - inaczej ruchać się, uprawiać seks.

Bzykają się najczęściej dziwkarze.

Pewien Marokańczyk bzyka się aż 7 razy dziennie.

Zastanawiać jednak może motywacja analizowanej treści semantycznej. Bez dogłębnej analizy materiału leksykograficznego epok minionych można by stwierdzić, że sens 'współżyć' wyrazu bzykać się rozwinął się w nawiązaniu do znaczenia leksemu gzić się, pokrewnego etymologicznie. Taka ścieżka rozwoju analizowanej treści jest jednak niemożliwa. Czasownik gzić się jest już bowiem wyrazem zleksykalizowanym, współcześni użytkownicy języka nie mogli zatem skojarzyć bzykania z gzami.

Sądzę więc, że sens 'odbywać stosunek seksualny' rozwinął się na skutek skojarzenia natarczywości owadów z napastliwym, nieraz wręcz agresywnym zachowaniem partnerów seksualnych (por. np. „Bzykamy się? Tak będzie ostro”, SSlang).

Prześledzenie zmian w znaczeniach czterech polskich wulgaryzmów, odnoszących się do stosunku seksualnego, tj.: gzić się, grzać się, parzyć się oraz bzykać się (oraz innych pokrewnych im wyrazów) pozwoliło stwierdzić, że u początków swej historii wszystkie wymienione czasowniki miały bardzo szerokie znaczenia, niezwiązane ze zwierzęcym popędem. Leksemami „zwierzęcymi” wyrazy te stawały się z kolei dopiero w połowie doby średniopolskiej.

O charakterze wulgarnym badanych słowoform można natomiast mówić dopiero w połowie XX wieku. W tym bowiem czasie wśród użytkowników polszczyzny kształtuje się świadomość językowa i upowszechnia pragnienie dbałości o kulturę języka (Pisarek, 2013, s. 323). 


\section{Wykaz skrótów}

SBań - Bańkowski A. 2000, Etymologiczny słownik języka polskiego, t. 1-2, Warszawa.

SBor - Boryś W. 2005, Stownik etymologiczny języka polskiego, Kraków.

SD - Doroszewski W. (red.) 1958-1969, Słownik języka polskiego, t. 1-11, Warszawa.

SL $\quad$ - Linde B. S. 1807-1814, Słownik języka polskiego, Warszawa.

SSlang - Miejski słownik slangu i mowy potocznej: http://www.miejski.pl/

SSław - Sławski F. 1952-1982, Słownik etymologiczny języka polskiego, Kraków.

SStp - Urbańczyk S. (red.) 1966-2000, Słownik staropolski, t. 1-11, Warszawa-Wrocław-Kraków.

SSyn - Synonimy net: http://synonim.net/synonim/kopulowa\%C4\%87

SW - Karłowicz J., Kryński A., Niedźwiedzki W. (red) 1900-1927, Słownikjęzyka polskiego, t. 1-8, Warszawa.

SWil - Zdanowicz A., Bohusz-Szyszko M. (red.) 1861, Słownik języka polskiego, t. 1-2. Wilno.

SXVI - Mayenowa M. R. (red) 1966, Słownik polszczyzny XVI wieku, Wrocław-Warszawa-Kraków.

SXVII - Gruszczyński W. (red.), Elektroniczny słownik XVII i pierwszej połowy XVIII wieku, online: http://sxvii.pl

USJP - Dubisz S. 2003, Uniwersalny słownik języka polskiego, Warszawa.

\section{Bibliografia}

Banaszak, J. (1994). Przegląd systematyczny owadów. Bydgoszcz: Wyższa Szkoła Pedagogiczna. Wydawnictwo Uczelniane.

Freud, Z. (1997). Totem i tabu. (J. Prokopiuk \& M. Poręba, Tłum.). Warszawa: Wydawnictwo Naukowe PWN.

Grochowski, M. (1995). Słownik polskich przekleństw i wulgaryzmów. Warszawa: Wydawnictwo Naukowe PWN.

Grybosiowa, A. (2003). Jak historyk języka polskiego rozumie opozycję homo - animal. Język a Kultura, 15, 9-15.

Krótki, Z. (2012). Pycha a świat zwierząt. W J. Przyklenk \& A. Rejter (Red.), Bogactwo polszczyzny w świetle jej historii (T. 4, ss. 97-109). Katowice: Wydawnictwo Uniwersytetu Śląskiego.

Krótki, Z. (2014). Eufemistyczne nazwy stosunku seksualnego w historii języka polskiego. W J. Przyklenk (Red.), Bogactwo polszczyzny w świetle jej historii (T. 5, ss. 140-153). Katowice: Wydawnictwo Uniwersytetu Śląskiego.

Leszczyński, Z. (1988). Szkice o tabu językowym. Lublin: Wydawnictwo Katolickiego Uniwersytetu Lubelskiego.

Pisarek, W. (2013). Troska o kulturę języka wczoraj i dziś. Język Polski, (5), 322-325.

Widłak, S. (1968). Zjawisko tabu językowego. Lud, 52, 7-25. 


\section{Słowniki}

Bańkowski, A. (2000). Etymologiczny słownikjęzyka polskiego (T. 1-2). Warszawa: Wydawnictwo Naukowe PWN.

Boryś, W. (2005). Słownik etymologiczny języka polskiego [SBor]. Kraków: Wydawnictwo Literackie.

Doroszewski, W. (Red.). (1958-1969). Słownikjęzyka polskiego [SD] (T. 1-11). Warszawa: Państwowe Wydawnictwo „Wiedza Powszechna”, Państwowe Wydawnictwo Naukowe.

Dubisz, S. (2003). Uniwersalny słownik języka polskiego [USJP]. Warszawa: Wydawnictwo Naukowe PWN.

Gruszczyński, W. (Red.). (b.d.). Elektroniczny słownik XVII i pierwszej połowy XVIII wieku [SXVII]. Pobrano 3 listopada 2016, z http://sxvii.pl

Karłowicz, J., Kryński, A., \& Niedźwiedzki, W. (Red). (1900-1927). Słownik języka polskiego [SW] (T. 1-8). Warszawa.

Linde, B. S. (1807-1814). Słownik języka polskiego [SL]. Warszawa: Drukarnia XX. Pijarów.

Mayenowa, M. R. (Red.). (1966-). Słownik polszczyzny XVI wieku [SXVI]. Wrocław, Warszawa, Kraków: Ossolineum.

Miejski słownik slangu i mowy potocznej [SSlang]. (b.d.). Pobrano 3 listopada 2016, z http:// www.miejski.pl/

Sławski, F. (1952-1982). Słownik etymologiczny języka polskiego [SSław]. Kraków: Towarzystwo Miłośników Języka Polskiego.

Synonimy net [SSyn]. (b.d.). Pobrano 3 listopada, 2016, z http://synonim.net/synonim/ kopulowa\%C4\%87

Urbańczyk S. (Red.). (1966-2000). Słownik staropolski [SStp] (T. 1-11). Warszawa, Wrocław, Kraków: IJP PAN.

Zdanowicz, A., \& Bohusz-Szyszko, M. (Red.). (1861). Słownik języka polskiego [SWil] (T. 1-2). Wilno.

\section{Z historii leksemów:}

\section{gzić się, grzać się, parzyć się, bzykać się}

W artykule poddano analizie semazjologicznej cztery polskie wulgaryzmy wiązane ze stosunkiem seksualnym, tj.: gzić się, grzać się, parzyć się i bzykać się. Wychodząc od etymologii, badano zmiany w znaczeniach tych jednostek.

Okazało się, że analizowane leksemy początkowo posiadały bardzo szerokie treści, dalekie ich współczesnej strukturze semantycznej. Sukcesywnie dochodziło jednak do przeszeregowania niektórych sensów, na skutek czego badane jednostki wpierw zaczęto odnosić do 
zwierzęcej kopulacji, natomiast nieco później do ludzkiego współżycia. Rolę wulgaryzmów analizowane czasowniki zaczęły odgrywać jednak dopiero w połowie XX wieku.

\section{Słowa kluczowe:}

semantyka, historia języka polskiego, tabu, wulgaryzm

\section{From the history of the lexemes gzić się, grzać się, parzyć się, bzykać się}

The present article undertakes a semasiological analysis of four Polish vulgarisms associated with sexual intercourse: gzić się, grzać się, parzyć się, bzykać się. Taking is the point of departure their etymology, it investigates the changes in the meanings of these units.

It was discovered that initially the analysed lexemes communicated a very wide range of content, far from their contemporary semantic structure. Successively, some senses some of their senses were rearranged, causing these units to become attributed to animal copulation and later to human sexual intercourse. However, it was until the mid- $20^{\text {th }}$ century that the analysed verbs have come to play the role of vulgarisms.

\section{Keywords:}

semantics, history of the Polish language, taboo, vulgarism 